(c) American Dairy Science Association, 2003.

\title{
Dietary Cation-Anion Difference and the Health and Production of Pasture-Fed Dairy Cows 2. Nonlactating Periparturient Cows
}

\author{
J. R. Roche ${ }^{*}{ }^{1}{ }^{1}$ D. Dalley, ${ }^{*}$ P. Moate, ${ }^{\star 2}$ C. Grainger, ${ }^{*}$ M. Rath, $\dagger$ and F. O’Mara \\ ${ }^{*}$ Agriculture Victoria Ellinbank, Victoria 3820, Australia \\ †Department of Animal Science and Production, \\ University College Dublin, Ireland
}

\section{ABSTRACT}

Anecdotal observations of reduced hypocalcemia due to small reductions in the precalving dietary cationanion difference (DCAD) are widely reported in Australia and New Zealand. Diets offered to nonlactating, periparturient dairy cows in pasture-based dairy systems in southeastern Australia can vary in their cation-anion difference from 0 to $+76 \mathrm{mEq} / 100 \mathrm{~g}$. The effects of such a range in the DCAD on the health and production of cows, on a pasture-based diet, were examined in an indoor feeding experiment. Four groups of four cows were offered pasture-hay and freshly cut pasture, a periparturient diet typical of that associated with the grazing system in Australia and New Zealand. Varying levels of salt supplementation were used to alter the dietary cation-anion difference, which ranged from -12 to $+69 \mathrm{mEq} / 100 \mathrm{~g}$. Blood and urine $\mathrm{pH}$ and mineral concentrations and urine hydroxyproline were measured. The addition of anions to the diet, to produce a negative DCAD, resulted in a nonrespiratory systemic acidosis. With decreasing $\mathrm{DCAD}$, the $\mathrm{pH}$ of blood and urine and the strong ion difference of urine decreased curvilinearly, blood bicarbonate decreased linearly and the urinary ratio of $\mathrm{Ca}$ to creatinine increased curvilinearly. Although systemic $\mathrm{pH}$ was not reduced at a DCAD of $+16 \mathrm{mEq} / 100 \mathrm{~g}$, urine Ca-to-creatinine ratio had begun to rise, probably indicating increased calcium absorption. The absorption and renal excretion of $\mathrm{Mg}$ increased with decreasing DCAD. No differences were observed in urine hydroxyproline concentrations and no significant differences in milk production were measured.

(Key words: hypocalcaemia, dietary cation-anion difference, pasture, potassium)

Received August 28, 2002.

Accepted September 10, 2002.

Corresponding author: J. Roche; e-mail: john.roche@dexcel.co.nz.

${ }^{1}$ Present address: Dexcel, Private Bag 3221, Hamilton, New Zealand.

${ }^{2}$ Present address: University of Pennsylvania, School of Veterinary Medicine, Biostatistics Section, Clinical Science, New Bolton Center, Kennett Square, PA 19348, USA.

\begin{abstract}
Abbreviation key: Creat $=$ creatinine, $\mathbf{D C A D}=$ dietary cation-anion difference, $\mathbf{D M D}=$ dry matter digestibility, Hy = hydroxyproline, ICP-ES = inductively coupled plasma emission spectrometry, $\mathbf{M E}=$ metabolizable energy.
\end{abstract}

\section{INTRODUCTION}

In the transition from pregnancy to lactation, the clearance of $\mathrm{Ca}$ to the placenta ceases, but the lactational Ca demand increases rapidly (Ramberg et al., 1984). Parturient hypocalcemia or paresis is a metabolic disorder caused by the increased demand placed on the plasma Ca pool by the sudden onset of lactation. More commonly known as milk fever, parturient paresis has been shown to affect approximately 2 to $5 \%$ of cows in Australia (Caple, 1987) and $2 \%$ of cows in New Zealand (McDougall, 2001). Although the mean incidence may be low, this ranges from 2 to $20 \%$ on individual farms (J. R. Roche, unpublished).

Plasma Ca concentration is under the control of parathyroid hormone, calcitonin, and the metabolites of vitamin D (Lindsay and Pethick, 1983). The losses of Ca from plasma may be regarded as disturbing signals to which these homeostatic mechanisms must respond to maintain eucalcemia (Ramberg et al., 1984). Hypocalcemia develops in most cows due to delays in these feedback mechanisms. However, in most animals, hypocalcemia is not severe enough to cause clinical signs, and blood Ca levels quickly return to normal (Ramberg et al., 1984; Goff and Horst, 1997b).

Stewart (1983) showed that the addition of anions to a solution decreased $\mathrm{pH}$. The addition of anions to body fluids through dietary supplementation should, therefore, decrease the $\mathrm{pH}$ of body fluids. Although blood $\mathrm{pH}$ is highly regulated, slight variations can affect $\mathrm{Ca}$ metabolism (Bushinsky et al., 1993; Schonewille et al., 1994) and a prepartum diet, with a negative dietary cation-anion difference (DCAD) has been shown to improve periparturient calcium homeostasis (Block, 1984; Goff et al., 1991; Joyce et al., 1997). A low urine pH, an indicator of blood $\mathrm{pH}$ (Vagnoni and Oetzel, 1998), has been associated with an increased gastrointestinal 
absorption and urinary output of $\mathrm{Ca}$ (Vagg and Payne, 1970; Schonewille et al., 1994). However Schonewille et al. (1994) reported that increased absorption of $\mathrm{Ca}$ accounted for only $60 \%$ of the increased excretion and concluded that $\mathrm{Ca}$ from another source was being added to the urinary $\mathrm{Ca}$ pool. The source of the additional $\mathrm{Ca}$ remains unclear.

One potential source of $\mathrm{Ca}$ is bone, through mobilization of Ca stores. Urinary hydroxyproline has been used in previous research as an indicator of bone resorption (Robins, 1994). However, results to date on the additional source of $\mathrm{Ca}$ are inconclusive. For example, in some experiments where DCAD was reduced (Block, 1984; Goff et al., 1991; Goff and Horst, 1997a), an increase in urinary hydroxyproline was reported. The findings of Bushinsky et al. (1993) on the effects of systemic acidosis on bone resorption agree with these results. In contrast, other researchers have found no difference in bone histomorphology or in the concentration of urinary hydroxyproline in nonlactating cows when DCAD was reduced and postulated that the other Ca source was decreased bone accretion (Schonewille et al., 1994; Van Mosel et al., 1994).

The dairying industry of southeastern Australia is largely perennial ryegrass-based and supplemented with cereal grain, pasture-hay, and pasture silage (Doyle et al., 1996). This diet has a very high DCAD (Jacobs and Rigby, 1999; Roche et al., 2000) and differs to that generally investigated as a precalving diet for cows in other countries. The DCAD of this diet can be as high as $+76 \mathrm{mEq} / 100 \mathrm{~g}$ (Roche et al., 2000), making a negative $\mathrm{DCAD}$, as is recommended in the literature, difficult and generally impractical to achieve. Nevertheless, the improved Ca homeostasis reported by Roche et al. (2002) in grazing animals receiving a DCAD of +15 to $+20 \mathrm{mEq} / \mathrm{kg}$ and anecdotal reports of reduced milk fever incidence when DCAD is marginally reduced demand an investigation of the DCAD concept as a means of preventing periparturient hypocalcemia in pasture-based cows. The objectives of this experiment were to compare a range of DCAD $(-10$ to $+65 \mathrm{mEq} / 100$ g) on a perennial ryegrass and pasture hay diet before calving, examining the effects on systemic $\mathrm{pH}$, milk fever, and subsequent lactation performance.

\section{MATERIALS AND METHODS}

\section{Experimental Design and Treatments}

A total of 16 multiparous Holstein cows, $19 \pm 5 \mathrm{~d}$ precalving, were randomly allocated to four dietary treatments in a randomized block design. Cows were allocated randomly to treatment using Baird's method (Harville, 1974; Baird, 1994) on the basis of total production for the previous lactation, and age. The cows were about to begin (mean \pm SD) lactation number $4 \pm$ 2.5 and had produced $5500 \pm 900 \mathrm{~kg}$ of milk the previous lactation with $4.4 \pm 0.53 \%$ fat and $3.2 \pm 0.14 \%$ protein.

\section{Feeds}

All cows were offered a daily diet of $5 \mathrm{~kg} \mathrm{DM}$ of pasture hay in the morning and $5 \mathrm{~kg} \mathrm{DM}$ of freshly cut pasture in the afternoon for $24 \pm 10 \mathrm{~d}$ before calving. After calving, the cows were switched to a ration of 6 $\mathrm{kg} \mathrm{DM}$ of barley and ad libitum freshly cut pasture for 3 wk. Ad libitum was defined as $110 \%$ of the pasture that had been eaten the previous day. The nutritive characteristics and mineral concentrations of the feeds offered are given in Table 1.

\section{Dietary Cation-Anion Difference}

The DCAD [ $(\mathrm{Na}+\mathrm{K})-(\mathrm{Cl}+\mathrm{S})$; Tucker et al., 1992] offered before calving was manipulated by adding salts of either $\mathrm{Na}, \mathrm{Cl}$, or $\mathrm{S}$ such that the four treatments received a planned DCAD of $-10,+15,+40$, and +65 $\mathrm{mEq} / 100 \mathrm{~g} \mathrm{DM}$.

Table 2 shows the salts used and the daily quantities that were administered before calving. The basal DCAD, based on previous work (Roche et al., 2000), was assumed to be approximately $+30 \mathrm{mEq} / 100 \mathrm{~g}$ DM. $\mathrm{MgSO}_{4}\left(\mathrm{MgSO}_{4} \cdot 7 \mathrm{H}_{2} \mathrm{O}\right), \mathrm{MgCl}_{2}\left(\mathrm{MgCl}_{2} \cdot 6 \mathrm{H}_{2} \mathrm{O}\right)$, and $\mathrm{CaCl}_{2}\left(\mathrm{CaCl}_{2} \cdot 2 \mathrm{H}_{2} \mathrm{O}\right)$ were used to reduce the DCAD, and $\mathrm{NaHCO}_{3}$ was used to increase it. $\mathrm{NaHCO}_{3}$ was chosen to increase the DCAD as it is the most commonly supplemented cationic salt in Australian situations. Furthermore, the findings reported by Goff and Horst (1997) showed that $\mathrm{Na}$ or $\mathrm{K}$ had similar effects on calcium homeostasis. $\mathrm{MgO}$ and $\mathrm{CaCO}_{3}$ were used to balance the dietary $\mathrm{Mg}$ and raise the dietary Ca concentrations (approximately 0.5 and $1.0 \%$, respectively).

Before calving, the cows received their appropriate salt mixture, twice daily, at 0600 and $1500 \mathrm{~h}$. If DCAD is to be accurately manipulated in pasture-based systems, it will be through supplementation of cows with appropriate salt mixtures once or twice daily, as the consistent and predictable manipulation of DCAD has been shown to be very difficult (Roche et al., 2002). Furthermore, the pasture-based system, where cows are generally a considerable distance from supplementation facilities precludes a more frequent supplementation strategy. In support of this method of supplementation, Roche (1999) showed increased Ca absorption and urinary $\mathrm{Ca}$ excretion and little or no diurnal variation in urine $\mathrm{pH}$ when anionic salts were supplemented twice daily to reduce the DCAD to $-20 \mathrm{mEq} /$ $100 \mathrm{~g}$, thereby suggesting that twice daily supplementation of anionic salts in pasture-based systems had similar effects to continuous supplementation in a TMR. 
Table 1. Mean DM (\%) and nutrient analysis (\% DM) of the feeds offered.

\begin{tabular}{|c|c|c|c|c|c|c|c|c|c|c|c|}
\hline & $\mathrm{DM}$ & $\mathrm{CP}$ & $\mathrm{DMD} \dagger$ & $\mathrm{ME} \ddagger$ & $\mathrm{K}$ & $\mathrm{Na}$ & $\mathrm{Cl}$ & $\mathrm{S}$ & $\mathrm{Mg}$ & $\mathrm{Ca}$ & $\mathrm{P}$ \\
\hline Pasture & 16.2 & 20.3 & 80 & 2.77 & 3.37 & 0.35 & 1.21 & 0.28 & 0.23 & 0.41 & 0.35 \\
\hline Barley & 89.0 & 12.7 & 79 & 2.72 & 0.49 & 0.11 & 0.18 & 0.11 & 0.12 & 0.04 & 0.26 \\
\hline Hay & 82.5 & 7.2 & 60 & 1.96 & 1.64 & 0.55 & 1.84 & 0.17 & 0.23 & 0.28 & 0.16 \\
\hline
\end{tabular}

$\dagger \mathrm{DMD}=$ In vitro DM digestibility.

$\$ \mathrm{ME}=$ Metabolizable energy $(\mathrm{Mcal} / \mathrm{kg}-$ calculated as $\mathrm{ME}=((\mathrm{DMD} * 0.17)-2) / 4.186))$ —Standing Committee on Agriculture, 1990.

As the DCAD of the diet was high, and the amounts of salts required to reduce or increase it to the predetermined levels were so great, the salts used were administered orally in solution using a stomach tube, as described by Roche et al. (2003).

\section{Animal Management}

Cows were individually fed for the duration of the experimental period. Feeds were offered daily for two 5-h periods. At 1200 to $1445 \mathrm{~h}$ and 2100 to $0545 \mathrm{~h}$, the cows were held as a single group on a bare paddock where water was available ad libitum.

After receiving their salt supplement, precalving, the cows received their morning and afternoon feed. They calved indoors and were monitored to determine the duration of calving. Calving time was deemed to be the time from first sign of the calf's hooves until the calf was born.

After calving, the cows were milked daily at 0600 and $1500 \mathrm{~h}$. They were then allowed access to half their daily allocation of barley for $20 \mathrm{~min}$ before being allowed access to fresh pasture.

The pastures used in this experiment had not been grazed for 6 to $7 \mathrm{wk}$ and were harvested at a mass of approximately $2500 \mathrm{~kg} \mathrm{DM} / \mathrm{ha}$. The pasture was cut to approximately $40 \mathrm{~mm}$, twice daily, and collected using a loader wagon. The cut pasture was not chopped further so as to best represent grazed pasture. The sward consisted of approximately $70 \%$ perennial ryegrass (Lolium perenne L.), $25 \%$ other grasses (Dactylus Glomerata, Holcus Lanatus and some Poa species), 2.5\% white clover (Trifolium repens) and $2.5 \%$ weeds on a

Table 2. Quantities of salts (g) administered daily to alter the dietary cation-anion difference $(\mathrm{mEq} / 100 \mathrm{~g})$ of a pasture:pasture hay diet and balance the diets for $\mathrm{Ca}$ and $\mathrm{Mg}$ concentration.

\begin{tabular}{lrrrr}
\hline Treatment & -12 & +16 & +51 & +69 \\
\hline $\mathrm{NaHCO}_{3}$ & 0 & 0 & 90 & 300 \\
$\mathrm{MgSO}_{4} \cdot 7 \mathrm{H}_{2} \mathrm{O}$ & 120 & 175 & 0 & 0 \\
$\mathrm{MgCl}_{2} \cdot 6 \mathrm{H}_{2} \mathrm{O}$ & 100 & 0 & 0 & 0 \\
$\mathrm{CaCl}_{2} \cdot 2 \mathrm{H}_{2} \mathrm{O}$ & 140 & 0 & 0 & 0 \\
$\mathrm{MgO}_{\mathrm{CaCO}}$ & 0 & 10 & 40 & 40 \\
\hline
\end{tabular}

DM basis. The hay was chopped to approximately 3 to $5 \mathrm{~cm}$ using a New Holland 717 flail harvester, and the barley was dry rolled prior to feeding.

\section{Measurements}

Cows were manually stimulated to urinate $3 \times$ each week before and after calving, and a sample of urine, from midstream, was collected in a 30-ml container. Within 30 min of collection, $\mathrm{pH}$ was measured, and 10 $\mathrm{ml}$ of sample was frozen for mineral, hydroxyproline, and creatinine (Creat) analysis. Urine minerals were determined by inductively coupled plasma emission spectrometry (ICP-ES), having been diluted with $1 \%$ nitric acid. Urine hydroxyproline was determined by a method developed by Parekh and Jung (1970), using a microplate reader (Biorad 550, BioRad, Hercules, CA). Urine creatinine was determined by a procedure modified from Bartels et al. (1972), using an autoanalyzer (Boehringer Manheim Hitachi 911).

Blood from the jugular vein was collected from each cow twice weekly for the duration of the experiment. Two samples were taken at each sampling. One sample was taken using a 10-ml heparinized syringe. Any excess air was immediately removed along with approximately $1 \mathrm{ml}$ of blood, and the syringe was stoppered and placed on ice. This aliquot was used to determine blood $\mathrm{pH}, \mathrm{pCO}_{2}$ and $\mathrm{pO}_{2}$, within 20 min of sampling, using a blood gas analyzer (Geprufte Sichereit, Italy). The second sample, taken using a $10-\mathrm{ml}$ heparinized evacuated tube, was centrifuged for $10 \mathrm{~min}$ at $1120 \times$ g. Following centrifugation, the plasma was pipetted off and frozen awaiting mineral analysis. Plasma minerals were determined by ICP-ES having been digested using nitric acid-assisted microwave digestion (Milestone Application Laboratory, 1995).

Individual milk yields were recorded daily, postcalving (Alpro milk meter system, Alfa Laval, Sweden). Fat, protein, and lactose concentrations of milk were determined by Milkoscan (Foss Electric, Hillerød, Denmark) on individual p.m. and a.m. aliquot samples collected for $2 \mathrm{~d}$ each week.

Dry matter intake were measured for each cow daily, and representative samples of each feed offered and 
refused were dried at $105^{\circ} \mathrm{C}$ to constant weight to determine DM content. Samples of all feeds were bulked on a weekly basis and dried at $65^{\circ} \mathrm{C}$ for $72 \mathrm{~h}$, ground to pass through a $0.5-\mathrm{mm}$ sieve (Christy Lab Mill, Ipswich, UK), and analyzed for in vitro DM digestibility (DMD), nitrogen, and macrominerals. Dry matter digestibility was determined by the method of Clarke et al. (1982). Metabolizable energy (ME - Mcal/kg DM) was calculated from DMD; $\mathrm{ME}=((\mathrm{DMD} * 0.17)-2) / 4.186$; Standing Committee on Agriculture, 1990).

The nitrogen content was determined by a Kjeldahl method using Buchi Kjeldahl nitrogen apparatus, with $\mathrm{CP}$ being calculated from nitrogen $\left(\mathrm{CP}=\mathrm{N}^{*} 6.25\right)$. Macrominerals were determined using X-ray spectroscopy (Hutton and Norrish, 1977; Norrish and Hutton, 1977).

\section{Calculations and Statistical Analysis}

Urinary minerals ( $\mathrm{Ca}, \mathrm{Mg}, \mathrm{Na}, \mathrm{Cl}, \mathrm{S})$ and hydroxyproline (Hy) are expressed as ratios to Creat concentration to overcome variations in urine volume among animals (Roche et al., 2002).

The strong ion difference (SID) is the difference, in milliequivalents, between certain cations and anions in body fluids and is calculated by subtracting the milliequivalents of $\mathrm{Cl}$ and $\mathrm{S}$ from the milliequivalents of $\mathrm{Na}$ and $\mathrm{K}$, in either plasma or urine $\left(\left[\mathrm{SID}_{\mathrm{b}}\right]\right.$ and $\left[\mathrm{SID}_{\mathrm{u}}\right]$, respectively).

The DCAD was calculated using the equation of Tucker et al. (1992) using the quantities of the salts administered and the measured mineral concentrations and DMI of all feeds.

$$
\mathrm{DCAD}=(\mathrm{Na}+\mathrm{K})-(\mathrm{Cl}+\mathrm{S})(\mathrm{mEq} / 100 \mathrm{~g} \mathrm{DM}) .
$$

Blood bicarbonate concentration was calculated from blood $\mathrm{pH}$ and $\mathrm{pCO}_{2}$ using the equations outlined by Tietz (1987).

For each cow, daily milk yields were averaged over a 17-d period beginning $4 \mathrm{~d}$ after calving. All data were analyzed using Genstat 5.4.1 (Genstat V, 1997) software, with cows as the experimental unit, according to a statistical model, which included effects for the four levels of treatment, linear, quadratic, and cubic trends with increasing DCAD and a covariate for previous season milk yield.

\section{RESULTS}

The DCAD eaten by cows on each treatment were $-12,+16,+51$, and $+69 \mathrm{mEq} / 100 \mathrm{~g}$ precalving, and +33 , $+34,+29$ and $+35 \mathrm{mEq} / 100 \mathrm{~g}$, postcalving.

The effect of treatment on precalving blood $\mathrm{pH}$, bicarbonate concentration, $\mathrm{pCO}_{2}, \mathrm{pO}_{2}$ and $\left[\mathrm{SID}_{\mathrm{b}}\right]$ and plasma
$\mathrm{Mg}$ and $\mathrm{Ca}$ concentrations are shown in Figure 1. The curvilinear decrease in blood $\mathrm{pH}$ with decreasing $\mathrm{DCAD}$ approached significance $(P<0.1)$, and cows receiving the lowest DCAD had a significantly lower blood $\mathrm{pH}$ than the other three treatments, which did not differ from each other. Precalving DCAD did not significantly affect blood $\mathrm{pCO}_{2}, \mathrm{pO}_{2}$, plasma $\mathrm{Ca}$, or $\left[\mathrm{SID}_{\mathrm{b}}\right]$, although bicarbonate concentration declined linearly with declining DCAD. The linear increase $(P<0.1)$ in plasma $\mathrm{Mg}$ concentrations precalving with decreasing DCAD (Figure 1) is consistent with there being a real trend. There were no significant effects of treatment on any other plasma mineral concentrations precalving, and there were no residual effects of precalving treatment on subsequent post-calving blood $\mathrm{pH}, \mathrm{pCO}_{2} \mathrm{pO}_{2}$ or $\left[\mathrm{SID}_{\mathrm{b}}\right]$ or plasma minerals (Table 3 ).

Treatment effects on urine variables are shown in Figure 2 and Table 4. Precalving urine $\mathrm{pH}$ and $\left[\mathrm{SID}_{\mathrm{u}}\right.$ ] decreased curvilinearly $(P<0.001$ and 0.1 , respectively $)$ with decreasing DCAD, but when offered a common diet after calving, there were no residual effects of precalving treatment on either (Table 4). The curvilinear increase in $\mathrm{Ca} /$ Creat and $\mathrm{Mg} /$ Creat $(P<0.1$ and 0.1 , respectively) with decreasing DCAD (Figure 2) is consistent with there being a real trend. Cl/Creat and S/ Creat also increased, precalving, as DCAD decreased $(P<0.01$ and 0.05 , respectively). Precalving $\mathrm{Na} / \mathrm{Creat}$ increased curvilinearly with increasing DCAD $(P<$ 0.01 ). There was no effect, either precalving or postcalving, of treatment on $\mathrm{Hy} / \mathrm{Creat}$. Postcalving, $\mathrm{Ca} / \mathrm{Creat}$ was significantly higher in cows receiving a precalving DCAD of $+16 \mathrm{mEq} / 100 \mathrm{~g}$ compared with cows that received a precalving DCAD of $+69 \mathrm{mEq} / 100 \mathrm{~g}$. There was no significant difference between the other treatments. There were no significant differences in the postcalving urinary concentrations of any of the other minerals (Table 4).

Precalving DMI did not decline until the day before calving, and varying the DCAD before calving did not significantly affect either pre- or postcalving total DMI or the yield or concentration of milk (Table 5). In the low DCAD treatment, two cows suffered clinical parturient paresis within $24 \mathrm{~h}$ of calving, while no cows in the other groups were clinically affected. There was no apparent trend in the effect of treatment on the duration of calving, although the cows receiving $+69 \mathrm{mEq} / 100 \mathrm{~g}$ calved in significantly less $(P<0.05)$ time than cows receiving either $+16 \mathrm{mEq} / 100 \mathrm{~g}$ or $+52 \mathrm{mEq} / 100 \mathrm{~g}$. Duration of calving ranged from $2 \mathrm{~min}$ to $60 \mathrm{~min}$.

\section{DISCUSSION}

Based on the lower blood and urine $\mathrm{pH}$, blood bicarbonate concentration and $\left[\mathrm{SID}_{\mathrm{u}}\right]$, with no obvious effect 

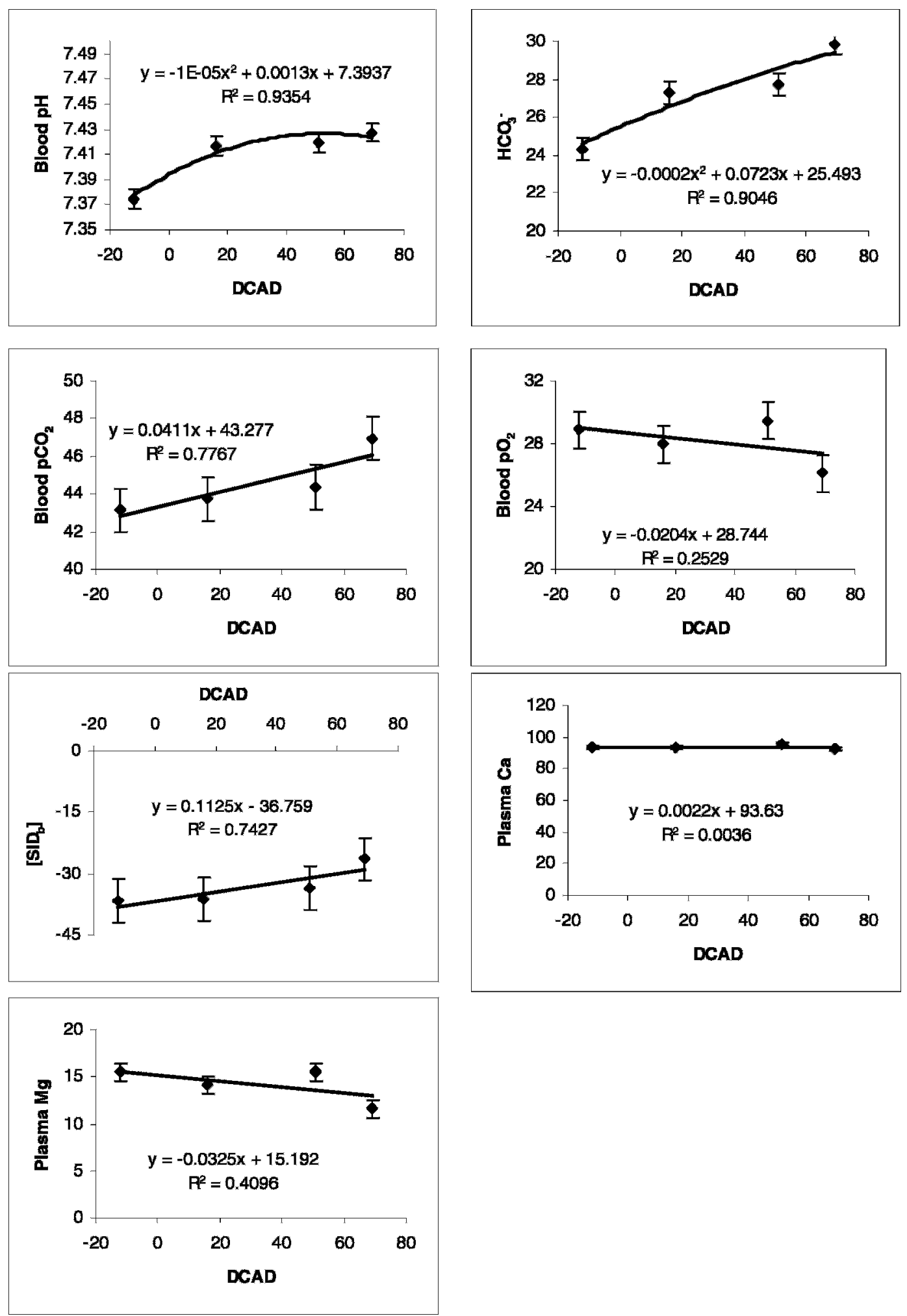

Figure 1. The effect of precalving dietary cation-anion difference $(\mathrm{DCAD} ; \mathrm{mEq} / 100 \mathrm{~g})$ on blood $\mathrm{pH}$, bicarbonate $\left(\mathrm{HCO}_{3}^{-} ; \mathrm{mEq} / \mathrm{L}\right), \mathrm{pCO}_{2}$ (Torr) and $\mathrm{pO}_{2}$ (Torr), plasma $\mathrm{Mg}(\mathrm{mg} / \mathrm{L})$ and $\mathrm{Ca}(\mathrm{mg} / \mathrm{L})$ and the Strong Ion Difference of blood $\left[\mathrm{SID}_{\mathrm{b}}\right]$, precalving. 
Table 3. Effects of precalving dietary cation-anion difference (DCAD) on blood $\mathrm{pH}, \mathrm{pCO}_{2}$ (Torr), $\mathrm{pO}_{2}$ (Torr), bicarbonate $\left(\mathrm{HCO}_{3}{ }^{-} ; \mathrm{mEq} / \mathrm{L}\right)$ and strong ion difference $\left[\mathrm{SID}_{\mathrm{b}}\right]$ and plasma mineral concentration $(\mathrm{mg} / \mathrm{l})$ of dairy cows after calving.

\begin{tabular}{lccccc}
\hline $\mathrm{DCAD}-\mathrm{mEq} / 100 \mathrm{~g}$ & -12 & +16 & +51 & +69 & \multicolumn{1}{c}{ SEM } \\
\hline $\mathrm{pH}$ & 7.400 & 7.402 & 7.393 & 7.402 & 0.008 \\
$\mathrm{HCO}_{3}{ }^{-}$ & 27.2 & 27.6 & 26.3 & 26.7 & 0.6 \\
$\mathrm{pCO}_{2}$ & 45.6 & 45.9 & 45.0 & 44.6 & 0.9 \\
$\mathrm{pO}_{2}$ & 30.6 & 27.8 & 31.1 & 29.9 & 1.6 \\
$\mathrm{Ca}$ & 87.5 & 91.6 & 92.6 & 89.8 & 1.0 \\
$\mathrm{Mg}$ & 14.3 & 16.1 & 17.8 & 13.1 & 1.9 \\
$\mathrm{~K}$ & 219 & 234 & 223 & 224 & 8 \\
$\mathrm{Na}$ & 2828 & 2758 & 3033 & 2808 & 172 \\
$\mathrm{Cl}$ & 3394 & 3442 & 3350 & 3767 & 166 \\
$\mathrm{~S}$ & 1022 & 984 & 1003 & 1036 & 30 \\
[SID $\left._{\mathrm{b}}\right]$ & -31.4 & -31.9 & -31.3 & -46.6 & 7.5 \\
\hline
\end{tabular}

on the partial pressure of either $\mathrm{CO}_{2}$ or $\mathrm{O}_{2}$ in blood, it was established that a reduction in the DCAD below $+16 \mathrm{mEq} / 100 \mathrm{~g}$ caused a nonrespiratory systemic acidosis. This supports the theory of Stewart (1981, 1983), that an increased dietary concentration of $\mathrm{Cl}$ and $\mathrm{S}$ would reduce the $\mathrm{pH}$ of body fluids. Blood mineral balance is tightly controlled, and so $\left[\mathrm{SID}_{\mathrm{b}}\right]$ was not significantly affected by treatment. This illustrates that more variables are involved in the control of systemic acidbase balance than [SID], as discussed by Stewart (1983) and Roche (1999). However, the significant decrease in urine $\mathrm{pH}$ and $\left[\mathrm{SID}_{\mathrm{u}}\right]$ as blood $\mathrm{pH}$ decreased show urine parameters to be strong indicators of the systemic acidbase status of the animal, a point also considered by Roche et al. (2000). In the current experiment, blood and urine $\mathrm{pH}$ and urine $\mathrm{Ca} /$ Creat were not affected unless the DCAD was reduced below $+16 \mathrm{mEq} / 100 \mathrm{~g}$. This supports the conclusions of Beede (1992) and those discussed by Roche et al. (2000), that a negative DCAD is required to alter blood $\mathrm{pH}$ and, hence, prevent milk fever. This requirement for such a low DCAD to alter systemic $\mathrm{pH}$ and urine $\mathrm{Ca} / \mathrm{Creat}$ (calcium absorption) and the lack of a change in these variables at higher DCAD was not known from previous research. These findings are of significant importance for pasture-based systems, where eucalcaemic benefits have been suggested from small changes in DCAD (reducing DCAD from +50 to $+30 \mathrm{mEq} / 100 \mathrm{~g}$ ). These results are also useful in determining the practicality of the DCAD concept as a means of preventing milk fever in pasturebased systems, as the volume of anionic salts required to reduce the DCAD sufficiently to alter calcium homeostasis would be large and, practically, very difficult to administer.

The concentration of $\mathrm{Mg}$ in plasma increased with decreasing DCAD, suggesting that metabolic acidosis increases the absorption of $\mathrm{Mg}$. The curvilinear increase in the renal excretion of $\mathrm{Mg}(\mathrm{Mg} / \mathrm{Creat})$ as DCAD decreased supports this. This was not evident from previ- ous work. The concentration of $\mathrm{Ca}$ in urine $(\mathrm{Ca} / \mathrm{Creat})$, an indicator of the Ca status of the animal, is also dependent on the net acid excretion of the body. Precalving $\mathrm{Ca} /$ Creat increased with the decrease in DCAD, although there was no increase in plasma Ca concentration. While Schonewille et al. (1994) and Van Mosel et al. (1994) have reported a similar result, others have measured an increase in plasma $\mathrm{Ca}$ at calving (Block, 1984) and for a short period ( 1 or $2 \mathrm{~d}$ ) postcalving. There is still debate as to the source of the additional Ca when such a diet is fed. Schonewille et al. (1994) measured an increase in absorption of $\mathrm{Ca}$, but found that it only accounted for approximately $60 \%$ of the increased excretion of $\mathrm{Ca}$. Another theoretical source of the excreted Ca may be the acidification of the medium surrounding bone, which can result in the release of $\mathrm{Ca}$ from the bone (Bushinsky et al., 1993). Many researchers have used the concentration of hydroxyproline in urine as an indicator of bone resorption (Robins, 1994; Russell, 1997). In this present work, no significant difference in Hy/Creat between treatments was found. This is supported by the work of Schonewille et al. (1994) and Van Mosel et al. (1994). Van Mosel et al. (1994) reported a decrease in bone accretion when DCAD was reduced but found no histomorphometric evidence of a change in bone resorption.

Chu et al. (1975) and Kim and Linkswiler (1979) found that an 'acidifying' diet, increased the urinary output of Ca due to an increased intestinal absorption, an increased glomerular filtration rate, and a reduced renal tubular reabsorption of $\mathrm{Ca}$, and not an increased resorption of bone. On the other hand, Block (1984), Leclerc and Block (1989) and Goff et al. (1991) measured an increase in urinary $\mathrm{Hy}$ as a result of feeding an acidogenic diet, suggesting that a reduction in blood $\mathrm{pH}$ did increase bone resorption. Hy may be derived from several different tissue sources such as the breakdown of collagen during uterine involution (Kaidi et al., 1991). A more likely cause of the increased urinary Hy 

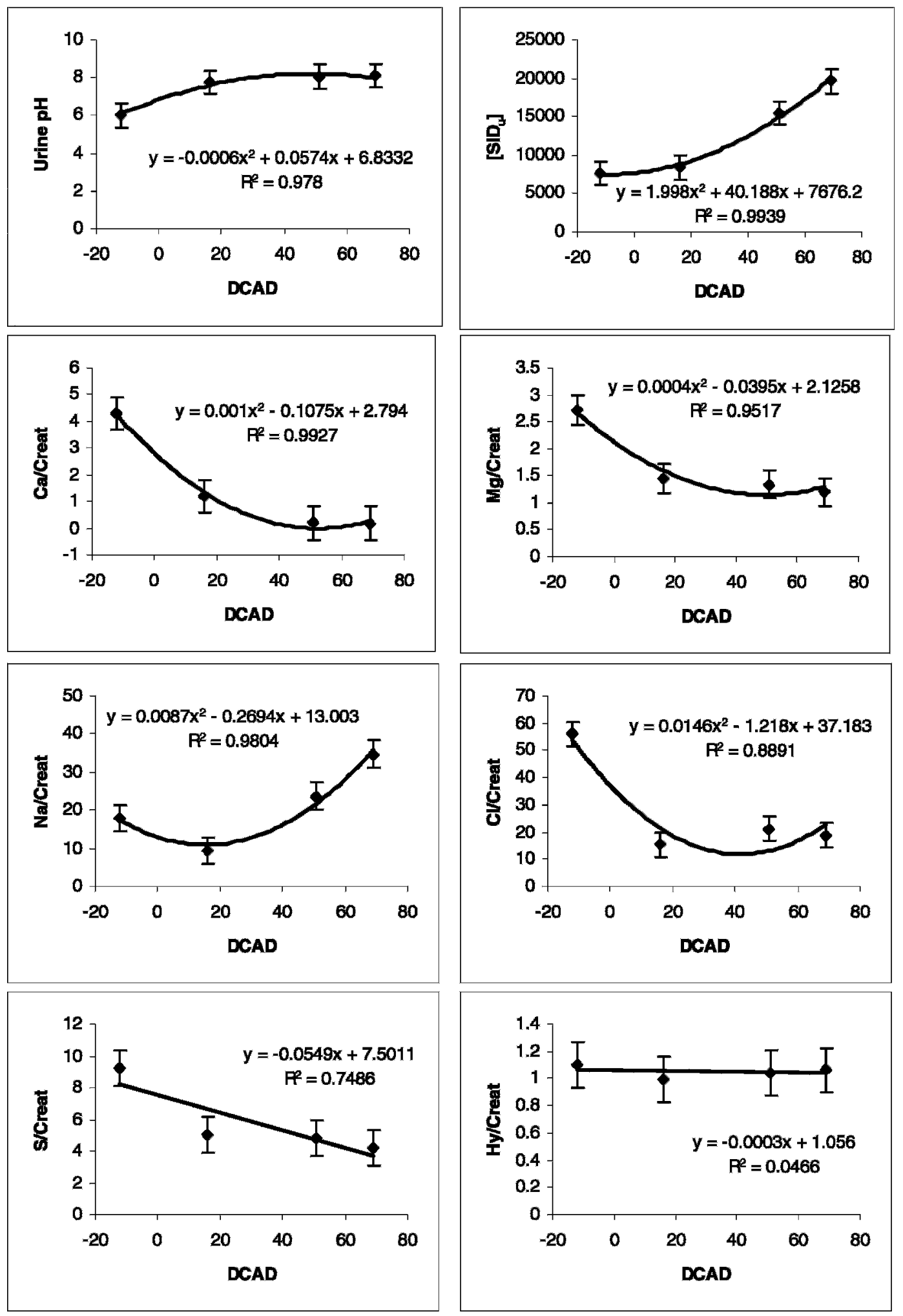

Figure 2. The effect of precalving dietary cation-anion difference (DCAD - mEq/100 g) on urine pH, urinary mineral and hydroxyproline (Hy) to creatinine (/creat) ratios and the strong ion difference of urine $\left[\mathrm{SID}_{\mathrm{u}}\right]$, precalving. 
Table 4. The effect of precalving dietary cation-anion difference (DCAD) on urine $\mathrm{pH}$ and urinary mineral and hydroxyproline (Hy) to creatinine ratios (/Creat) after calving.

\begin{tabular}{lccccc}
\hline $\mathrm{DCAD}-\mathrm{mEq} / 100 \mathrm{~g}$ & -12 & +16 & +51 & +69 & SEM \\
\hline Urine $\mathrm{pH}$ & 7.76 & 8.04 & 8.02 & 7.90 & 0.11 \\
$\mathrm{Ca} /$ Creat & 0.17 & 0.16 & 0.14 & 0.09 & 0.06 \\
$\mathrm{Mg} /$ Creat & 0.78 & 0.61 & 1.02 & 0.44 & 0.21 \\
$\mathrm{~K} /$ Creat & 35.6 & 41.6 & 47.4 & 37.5 & 4.7 \\
Na/Creat & 3.8 & 2.0 & 5.9 & 3.2 & 1.9 \\
Cl/Creat & 17.6 & 16.0 & 19.1 & 17.5 & 2.3 \\
S/Creat & 3.2 & 3.2 & 2.9 & 2.9 & 0.5 \\
Hy/Creat & 2.17 & 2.19 & 1.97 & 2.43 & 0.36 \\
\hline
\end{tabular}

concentration in the prepartum cow is an increased rate of hydrolysis of extraskeletal connective tissue components (Galambos et al., 1976). Therefore, an effect of treatment on urine Hy concentration cannot be assumed to be solely due to bone resorption without additional measurements to support this.

Despite the low DCAD treatment group having a higher $\mathrm{Ca} / \mathrm{Creat}$, it was the only treatment to experience clinical hypocalcemia (two cows). This is in direct contrast to previous research findings where a reduction in DCAD before calving was associated with a reduced incidence of hypocalcemia (Block, 1984; Oetzel et al., 1988). Perennial ryegrass-dominant pastures in southeast Australia typically have 3 to $4.5 \mathrm{~g} \mathrm{Ca} / \mathrm{kg} \mathrm{DM}$, while the main supplement, barley, has less than $1 \mathrm{~g}$ of $\mathrm{Ca} / \mathrm{kg} \mathrm{DM}$ (Jacobs and Rigby, 1999). This diet is marginal in its ability to meet the Ca requirements of freshly-calved cows. However, animals fed a diet high in strong anions reabsorb less $\mathrm{Ca}$ in the renal tubules (Kim and Linkswiler, 1979) and, thus, probably require more dietary Ca to maintain a positive Ca balance (Linkswiler et al., 1981). In this experiment, therefore, a reduction in the DCAD offered to dry cows may have created a greater demand for Ca postcalving in order to prevent an accession of milk fever. This finding was not evident from previous work. In essence, although postcalving Ca supplementation should be regarded as important in all periparturient cows, it appears to be more important if cows are fed a negative DCAD or have been supplemented with anionic salts prior to calving.

The consequences of substantially altering the DCAD on perennial ryegrass-based systems as are found in Australia, New Zealand, and Western Europe were not known from previous work.

\section{CONCLUSIONS}

In pasture-based dairying systems, blood $\mathrm{pH}$ and urine $\mathrm{pH}$ are reduced when a ration with a negative DCAD is fed. Achievement of a diet with a negative DCAD also resulted in an increased urinary output of Ca. No significant differences in milk production through altering the precalving DCAD were detected. Due to the high DCAD in the base diet offered to pasture-fed dairy cows and the requirement for a negative DCAD to increase $\mathrm{Ca}$ absorption, it is unlikely that the DCAD concept is a practical means of preventing milk fever in pasture-fed cows.

Table 5. The effect of precalving dietary cation-anion difference (DCAD) on 17-d mean milk yield and composition, DMI and duration of calving.

\begin{tabular}{|c|c|c|c|c|c|}
\hline DCAD - mEq/100 g & -12 & +16 & +51 & +69 & SEM \\
\hline \multicolumn{6}{|l|}{ Yield, kg/c/d } \\
\hline Milk & 26.3 & 29.5 & 29.8 & 28.4 & 1.9 \\
\hline Fat & 1.10 & 1.24 & 1.22 & 1.16 & 0.13 \\
\hline Protein & 0.79 & 0.99 & 0.93 & 0.96 & 0.05 \\
\hline Lactose & 1.24 & 1.51 & 1.46 & 1.46 & 0.06 \\
\hline \multicolumn{6}{|l|}{ Concentration, \% } \\
\hline Fat & 4.34 & 4.07 & 4.21 & 4.37 & 0.25 \\
\hline Protein & 3.04 & 3.37 & 3.18 & 3.40 & 0.11 \\
\hline Lactose & 4.77 & 5.09 & 4.92 & 5.14 & 0.13 \\
\hline Precalving total DMI, $\mathrm{kg} / \mathrm{c} / \mathrm{d}$ & 7.9 & 9.3 & 8.7 & 8.9 & 0.5 \\
\hline Postcalving total DMI, $\mathrm{kg} / \mathrm{c} / \mathrm{d}$ & 11.8 & 14.0 & 12.4 & 13.0 & 1.2 \\
\hline Time spent calving, min & $23^{\mathrm{ab}}$ & $37^{\mathrm{b}}$ & $33^{\mathrm{b}}$ & $4^{\mathrm{a}}$ & 8.4 \\
\hline
\end{tabular}

${ }^{\mathrm{a}, \mathrm{b}} \mathrm{Means}$ in a row with different superscripts differ significantly $(P<0.05)$. 


\section{ACKNOWLEDGMENTS}

The authors acknowledge the technical assistance of P. Durling, G. Lineham, K. Baum, D. Wilson, J. Laidlaw, S. Laidlaw, M. Davies, and A. Green, the statistical expertise of M. Hannah, and all the help afforded them by farm staff.

\section{REFERENCES}

Australian Government. 1990. Australian code of practice for the care and use of animals for scientific purposes. Australian Government Publishing Service, Canberra, Australia.

Baird, D. B. 1994. The design of experiments with covariates. Ph.D. Diss., Univ. Otago, New Zealand.

Bartels. H., M. Boemer, and C. Heirli. 1972. Serum creatinine determination without deproteinization. Clin. Chim. Acta 37:193-197.

Beede, D. K. 1992. The DCAD concept: transition rations for dry pregnant cows. Feedstuffs 64:10-19.

Block, E. 1984. Manipulating dietary anions and cations for prepartum dairy cows to reduce incidence of milk fever. J. Dairy Sci. 67:2939-2948.

Bushinsky, D. A., W. Wolbach, N. Sessler, R. Mogilevsky, and R. Levi-Setti. 1993. Physicochemical effects of acidosis on bone calcium flux and surface ion composition. J. Bone Min. Res. 8:93-102.

Caple I. W. 1987. Unravelling mineral and metabolic problems in dairy herds. Pages 19-21 in Australian Advances in Veterinary Science. Proc. 64th Annu. Conf. Aus. Vet. Assoc.

Chu, J. Y., S. Margen, and F. M. Costa. 1975. Studies in calcium metabolism. 2. Effects of low calcium and variable protein intake on human calcium metabolism. Am. J. Clin. Nutr. 28:1028-1035.

Clarke, T., P. C. Flinn, and A. A. McGowan. 1982. Low-cost pepsincellulase assays for the prediction of digestibility of herbage. Grass Forage Sci. 37:147-150

Dalley, D. E. 1994. Within herd variability in the mineral status of grazing dairy cows in early lactation. Pages $27-30$ in Proc. 54th N.Z. Soc. Anim. Prod.

Doyle, P. T., C. R. Stockdale, and A. R. Lawson. 1996. Pastures for dairy production in Victoria. Agriculture Victoria, Australia.

Genstat V. 1997. Genstat 5, Release 4.1, Reference Manual. Oxford Univ. Press, Oxford, United Kingdom.

Goff, J. P., R. L. Horst, F. J. Mueller, J. K. Miller, G. A. Kiess, and H. H. Dowlen. 1991. Addition of chloride to a prepartal diet high in cations increases 1,25-dihydroxyvitamin $D$ response to hypocalcemia preventing milk fever. J. Dairy Sci. 74:3863-3871.

Goff, J. P., and R. L. Horst. 1997a. Effects of the addition of potassium or sodium but not calcium, to prepartum rations on milk fever in dairy cows. J. Dairy Sci. 80:176-186.

Goff, J. P., and R. L. Horst. 1997b. Physiological changes at parturition and their relationship to metabolic disorders. J. Dairy Sci. 80:1260-1268

Harville, D. A. 1974. Nearly optimal allocation of experimental units using observed covariate values. Technometrics 16:589-599.

Hutton, J. T., and K. Norrish. 1977. Plant analyses by x-ray spectrometry. 2. Elements of atomic number greater than 20. X-Ray Spectrometry. 6:12-17.

Jacobs, J. L., and S. E. Rigby. 1999. Minerals in dairy pastures in Victoria. Dep. of Natural Resources Environment, Melbourne.

Joyce, P. W., W. K. Sanchez, and J. P. Goff. 1997. Effect of anionic salts in prepartum diets based on alfalfa. J. Dairy Sci. 80:2866-2875.

Kaidi, R., P. J. Brown, J. S. E. David, D. J. Etherington, and S. P. Robins. 1991. Uterine collagen during involution in cattle. Matrix 11:101@Dnd107.

Kim, Y., and H. M. Linkswiler. 1979. Effect of level of protein intake on calcium metabolism and on parathyroid and renal function in the adult human male. J. Nutr. 109:1399-1404.

Leclerc, H., and E. Block. 1989. Effects of reducing dietary cationanion balance for prepartum dairy cows with specific reference to hypocalcaemic parturient paresis. Can. J. Anim. Sci. 69:411-423.
Lindsay, D. B., and D. W. Pethick. 1983. Adaptation of metabolism to various conditions: metabolic disorders. Pages $431-480$ in Dynamic Biochemistry of Animal Production. Neimann-Sorensen and Tribe, D. E. (ed). World Animal Science. Series A, Basic Information.

Linkswiler, H. M., M. B. Zemel, M. Hegsted, and S. Schuette. 1981. Protein-induced hypercalciuria. Federation Proc. 40:2429-2433.

McDougall, S. 2001. Effects of periparturient diseases and conditions on the reproductive performance of New Zealand dairy cows. N.Z. Vet. J. 49:60-67.

Milestone Application Laboratory. 1995. Milestone application notes for microwave digestion. Application Note 23.

Norrish, K., and J. T. Hutton. 1977. Plant analyses by x-ray spectrometry. 1. Low atomic number elements, sodium to calcium. X-Ray Spectrometry 6:6-11.

Oetzel, G. R., J. D. Olson, C. R. Curtis, and M. J. Fettman. 1988 Ammonium chloride and ammonium sulphate for prevention of parturient paresis in dairy cows. J. Dairy Sci. 71:3302-3309.

Parekh, A. C., and D. H. Jung. 1970. An improved method for determination of total hydroxyproline in urine. Biochemical Medicine $4: 446-456$.

Ramberg, C. F., G. P. Mayer, D. S. Kronfeld, J. M. Phang, and M. Berman. 1984. Calcium homeostasis in cows, with special reference to parturient hypocalcaemia. Am. J. Phys. 246:698-704.

Robins, S. P. 1994. Biochemical markers for assessing skeletal growth. Eur. J. Clin. Nutr. 48:199-209.

Roche, J. R. 1999. Dietary Cation-Anion Difference for Grass-fed Dairy Cows. Ph.D. Diss., Univ. College, Dublin.

Roche, J. R., D. E. Dalley, P. J. Moate, C. Grainger, M. Hannah, F. O'Mara, and M. Rath. 2000. Variations in the dietary cationanion difference and the acid-base balance of dairy cows on a pasture-based diet in south-eastern Australia. Grass Forage Sci. $55: 26-36$.

Roche, J. R., J. Morton, and E. S. Kolver. 2002. Sulfur and chlorine play a non-acid base role in periparturient calcium homeostasis. J. Dairy Sci. 85:3444-3453.

Roche, J. R., D. E. Dalley, P. Moate, C. Grainger, M. Rath, and F. O'Mara. 2003. Dietary cation-anion difference and the health and production of pasture-fed dairy cows. 1. Dairy cows in early lactation. J. Dairy Sci. 86:970-978.

Russell, R. G. G. 1997. The assessment of bone metabolism in vivo using biochemical markers. Hormone and Metabolic Res. 29:138-144.

Schonewille, J. T., A. T. Van't Klooster, A. Dirkswager, and A. Bayen. 1994. Stimulatory effect of an anion (chloride)-rich ration on apparent calcium absorption in dairy cows. Livest. Prod. Sci. 40:233-240.

Standing Committee on Agriculture (SCA). 1990. Feeding Standards for Australian Livestock-Ruminants. In Ruminants. Ruminants Subcommittee (ed.) Melbourne: CSIRO Publ.

Stewart, P. A. 1981. How to understand acid-base-A quantitative acid-base primer for biology and medicine. Edward Arnold, London.

Stewart, P. A. 1983. Modern quantitative acid-base chemistry. Can. J. Physiol. Pharmacol. 61:1444-1461.

Tietz, N. W. 1987. The fundamentals of clinical chemistry. W.B. Saunders, Philadelphia.

Tucker, W. B., J. F. Hogue, D. F. Waterman, T. S. Swenson, Z. Xin, R. W. Hemken, J. A. Jackson, G. D. Adams, and L. J. Spicer. 1992. Sulfur should be included when calculating the dietary cation-anion balance of diets for lactating dairy cows. Pages 141150 in Anim. Sci. Res. Rep., Oklahoma Res. Stn.

Vagg, M. J., and J. M. Payne. 1970. The effect of ammonium chloride induced acidosis on calcium metabolism in ruminants. Br. Vet. J. 126:530-537.

Vagnoni, D. B., and G. R. Oetzel. 1998. Effects of dietary cationanion difference on the acid-base status of dry cows. J. Dairy Sci. 81:1643-1652.

Van Mosel, M., H. S. Wouterse, and A. T. Van't Klooster. 1994. Effects of reducing dietary $([\mathrm{Na}+\mathrm{K}]-[\mathrm{Cl}+\mathrm{S}])$ on bone in dairy cows at parturition. Res. Vet. Sci. 56:270-276. 